\title{
Triangular umbilicoplasty with skin flap
}

\section{Umbilicoplastia triangular com retalho dérmico}

\author{
João Francisco do Valle \\ Pereira $^{1}$ \\ LUCIANO VARgas SChUTZ ${ }^{2}$ \\ Velibor Kostic ${ }^{3}$ \\ Conrado Luiz Pais \\ D'Avila $^{4}$
}

Felipe Nascimento Mateus ${ }^{5}$

Study conducted at Clínica Valle Pereira, Florianópolis, SC, Brazil.

Submitted to SGP (Sistema de Gestão de Publicações/Manager

Publications System) of RBCP

(Revista Brasileira de Cirurgia Plástica/Brazilian Journal of Plastic

Surgery)

Received: June 20, 2011 Accepted: July 29, 2011

\begin{abstract}
Background: Umbilicoplasty techniques vary greatly, in both the manner in which the incision the umbilical scar is incised, as well as the manner in which the skin of the abdominal flap is opened and repaired at the aponeurosis and/or the umbilical stump. As the postoperative appearance of the umbilical scar is aesthetically unsatisfying, the authors sought to develop a new technique aimed at providing patients with a greater degree of aesthetic and postoperative satisfaction. Methods: The abdominoplasties included in this study were performed in 194 patients at Clínica Valle Pereira (Florianópolis, SC) between February 2009 and January 2011. All patients underwent conventional abdominoplasties and triangular umbilicoplasties with skin flaps. Results: Only 8 (4.13\%) patients had mild complications. There were no severe complications. Positive satisfaction was reported by patients in $188(96.91 \%)$ cases and by surgeons in $186(95.88 \%)$ cases. Conclusions: The technique described in this study demonstrates versatility, simplicity in application, and reproducibility, bringing greater harmony in body contouring and improved appearance of the umbilical scar, a major stigma of abdominoplasty.
\end{abstract}

Keywords: Abdomen/surgery. Umbilicus/surgery Surgical flaps.

\section{RESUMO}

Introdução: A técnica de umbilicoplastia varia muito, tanto na forma como é incisada a cicatriz umbilical, quanto na abertura cutânea no retalho abdominal e sua fixação na aponeurose e/ou coto umbilical. Descontentes com o aspecto pós-operatório da cicatriz umbilical, os autores viram a necessidade de desenvolver uma nova técnica, com o objetivo de proporcionar aos pacientes maior grau de naturalidade e satisfação pós-operatória. Método: Foram incluídas neste estudo as abdominoplastias realizadas na Clínica Valle Pereira (Florianópolis, SC), no período compreendido entre fevereiro de 2009 e janeiro de 2011, totalizando 194 pacientes. Todos os pacientes foram submetidos a abdominoplastia convencional e umbilicoplastia triangular com retalho dérmico. Resultados: Apenas 8 (4,13\%) pacientes apresentaram complicações leves. Não houve complicações graves. A satisfação dos pacientes foi positiva em $188(96,91 \%)$ casos; entre os cirurgiões, a satisfação foi positiva em $186(95,88 \%)$ casos. Conclusões: A técnica demonstra versatilidade, facilidade de execução e reprodutibilidade, proporcionando harmonia no contorno corporal e naturalidade ao principal estigma da abdominoplastia, a cicatriz umbilical.

Descritores: Abdome/cirurgia. Umbigo/cirurgia. Retalhos cirúrgicos.

1. President of the Brazilian Society of Plastic Surgery (SBCP) - Santa Catarina Section (between 1988 and 1989), member of the Committee for Awards of SBCP, Florianópolis, SC, Brazil.

2. President of the SBCP - Santa Catarina Section, Florianópolis, SC, Brazil.

3. Plastic surgeon, full member of the SBCP, Florianópolis, SC, Brazil.

4. Specialist physician of the SBCP, Florianópolis, SC, Brazil.

5. Resident physician in Plastic Surgery at Hospital Cajuru, Pontifícia Universidade Católica do Paraná (PUC/PR), Curitiba, PR, Brazil. 


\section{INTRODUCTION}

Abdominal plastic surgery has been practiced since the late nineteenth century. The first descriptions of abdominal dermal-adipose resections were reported in 1890 by Voloir, Demars, and Marx. Since that time, several technical modifications have been made, and continuing enhancements have been reported in the quest for superior outcomes ${ }^{1,2}$. In early abdominoplasties, little or no attention was paid to the umbilical scar, which was frequently excised with an excess of dermal-adipose tissue. For aesthetic reasons, some surgeons began to preserve the umbilical scar, maintaining it in its normal position ${ }^{1}$.

Umbilicoplasty techniques vary greatly, in both the manner in which the umbilical scar is incised, as well as the manner in which the skin opening in the abdominal flap is opened and repaired at the aponeurosis and/or the umbilical stump $^{3-7}$.

Operated abdomens are frequently associated with the stigma of an umbilical scar based on two reasons: the positioning of the scar and/or the transverse aspect of the new umbilicus ${ }^{8}$. Multiple surgical techniques have been described in order to avoid this stigma, including those published by Baroudi ${ }^{6}$, in 1975; Avelar ${ }^{7}$, in 1978; and recently, D’Assumpção ${ }^{8}$, in 2005.

Thus, dissatisfaction with the appearance of the umbilical scar has fostered the desire to develop a new technique aimed at providing patients with an improved appearance at the surgical area and greater postoperative satisfaction.

\section{METHODS}

This study included 194 patients who underwent abdominoplasty and umbilicoplasty by triangular technique with a skin flap between February 2009 and January 2011 at Clínica Valle Pereira (Florianópolis, SC). All patients were monitored postoperatively. This technique has been used by the authors since April 2004.

The abdominoplasties were performed with the patient under epidural anesthesia with electrocautery by means of a lower transverse incision in a slightly concave upwards pattern, with moderate detachment of the flap along the infraumbilical supra-aponeurotic plane and in the tunnel of the supraumbilical region. Aponeurosis plication of rectus abdominis muscles was performed with the application of some sutures in an " $X$ " pattern with 2.0 monofilament nylon sutures, followed by a whipstitch suture with Vicryl 0 . Adhesion sutures consisted of Vicryl 0, and were applied as described by Baroudi ${ }^{6}$. In most cases, liposuction of the entire flap was performed prior to abdominoplasty, without the use of any type of drainage.

The umbilicoplasty was performed by triangulartechnique with a dermal flap. This technique was performed by isolating the umbilicus from the detached flap by an incision that circumscribed the flap, thereby maintaining the flap in its original position (Figure 1).

After the complete detachment of the abdominal flap, aponeurosis plication of the rectus muscles was performed in the following sequence. The excess umbilical tissue was resected with skin scissors preparing the region in the shape of an equilateral triangle with a lower base, with a mean distance of $1.5 \mathrm{~cm}$ on each side. The umbilical stump was affixed with 2 " $\mathrm{X}$ " sutures using 2.0 monofilament nylon thread, 1 at the apex of the triangle and another at its base (Figures 2 and 3).

Baroudi sutures were first applied to the supraumbilical region, fixing and gently pulling the flap towards the

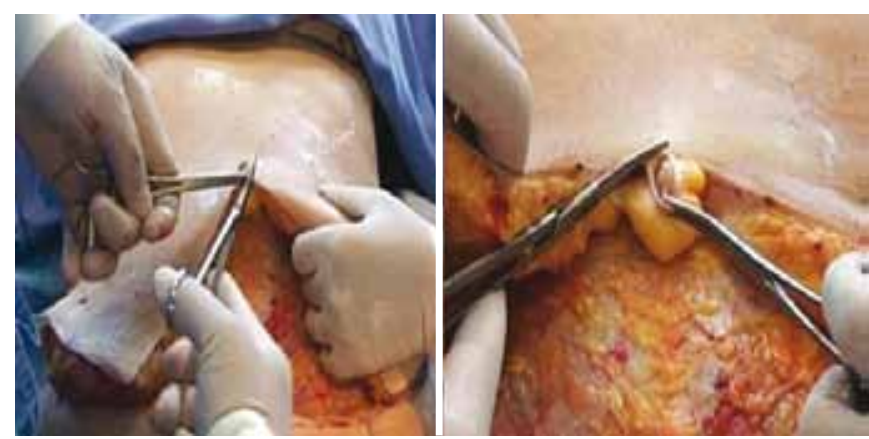

Figure 1 - Isolation of the umbilical scar from the abdominal flap.
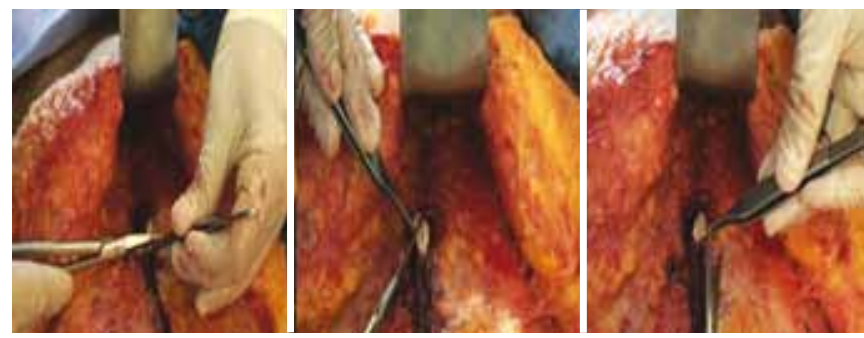

Figure 2 - Umbilical stump shaped into a lower base triangle.
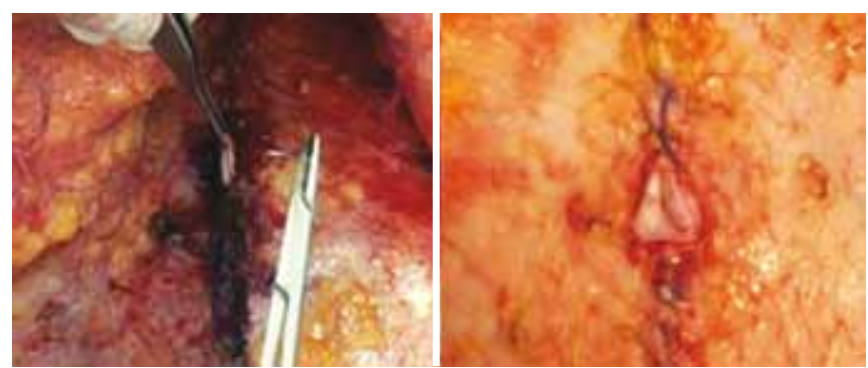

Figure 3 - Fixing the umbilical stump in the aponeurosis of the rectus muscles. 
umbilical stump. After several of these sutures were applied, the flap was pulled in an inferior direction, thereby identifying the exact projection point of the umbilical stump in the abdominal flap. This marking was performed in the form of a lower base triangle, coinciding with the shape of the umbilical stump and also measuring a mean of $1.5 \mathrm{~cm}$ on each side. After marking, de-epidermization of this triangle was performed (Figure 4).

Next, an incision in this triangle was performed, aimed at removing a "cork" of dermis and adipose tissue; however, the 3 vertices of the triangle with a substantial amount of dermis were retained (Figures 5 and 6).

Next, the abdominal flap was fixed in the aponeurosis of the rectus abdominis muscles and in the umbilical stump. The
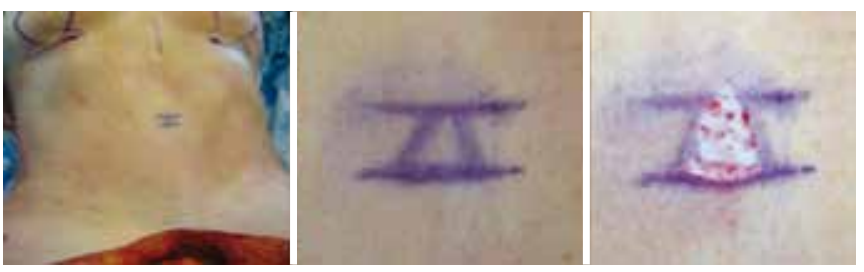

Figure 4-Marking the lower base triangle in the proper projection of the umbilical stump at the abdominal flap, and subsequent deepidermization.

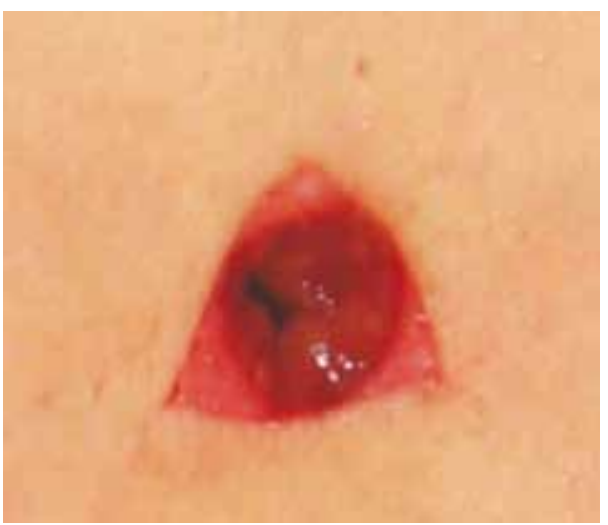

Figure 5 - Incision into the lower base triangle while maintaining the 3 dermal vertices.
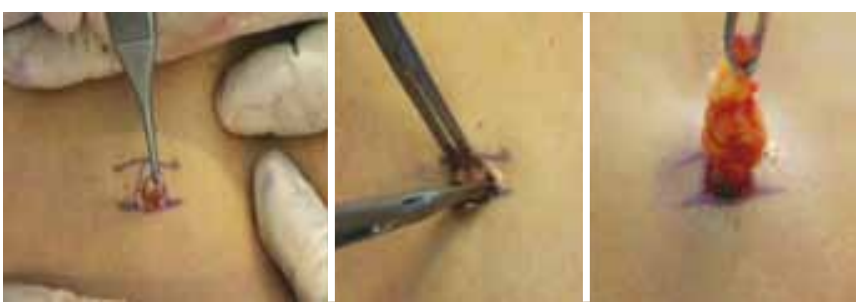

Figure 6-Dermal-adipose "cork" resection in the new umbilical position. first step was a maneuver with the upper end of the triangle, using monofilament nylon 2.0 thread with a reversed simple suture, first by passing through the de-epidermized portion with a substantial amount of dermis, second by passing through the aponeurosis, and finally, by passing through the umbilical stump dermis, also situated in its upper end (Figures 7 to 10 ).

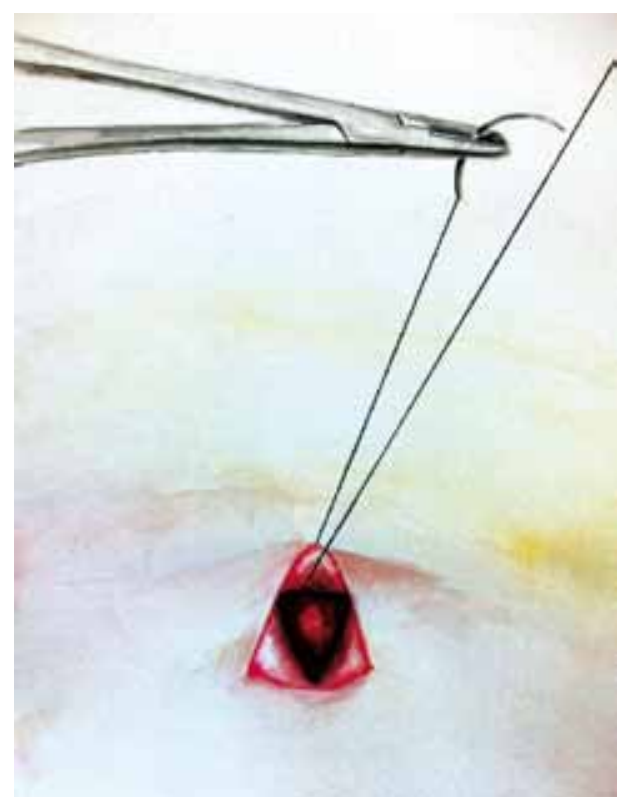

Figure 7 - Illustration of the first suture to be performed in the umbilicoplasty: simple suture inverted with 2.0 monofilament nylon thread, in the upper dermal vertex of the de-epidermized triangle in the flap.

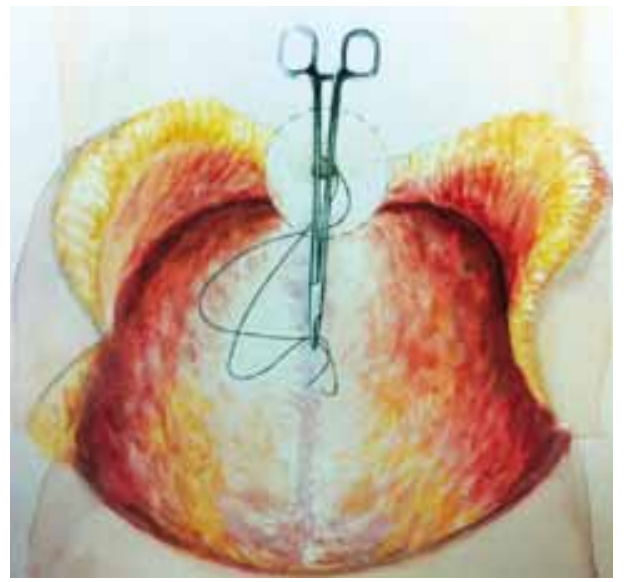

Figure 8 -Illustration of the transference maneuver of the needle holder with 2.0 monofilament nylon thread repaired into the hole of the new umbilical position, in the abdominal flap after the step described in Figure 7, in order to continue fixing the abdominal flap in the aponeurosis and the umbilical stump. 


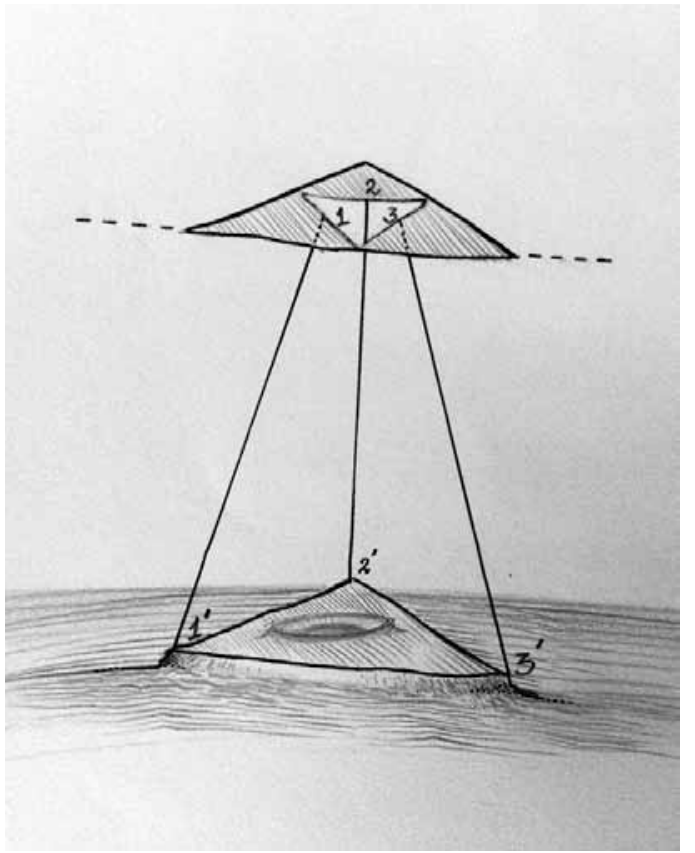

Figure 9 - Scheme of abdominal flap fixing in the aponeurosis and the umbilical stump. 2.0 monofilament nylon thread was used to make 3 points, bringing together the reference points of the flap and the aponeurosis/umbilical stump, 1 to 1 ', 2 to 2 ', and 3 to 3 '.
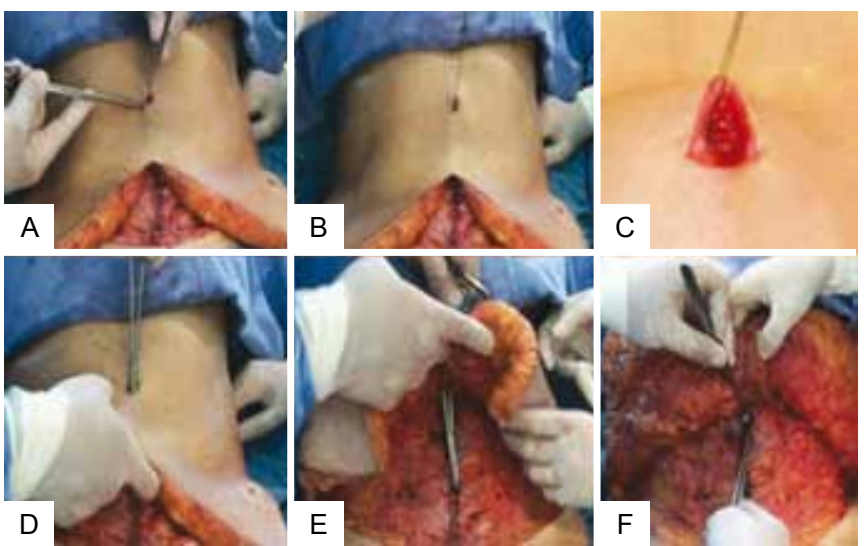

Figure 10 - Fixing the flap in the aponeurosis and the umbilical stump - first point: upper vertex of the triangle. In A, a simple inverted point is made in the upper dermal vertex of the triangle. In $\boldsymbol{B}$ and $\boldsymbol{C}$, point passed in the upper dermal vertex and repaired by the needle holder. In $\boldsymbol{D}$ and $\boldsymbol{E}$, a transfer maneuver of the repaired thread by the needle holder inside the hole of the abdominal flap. In

$\boldsymbol{F}$, fixing the flap in the aponeurosis and umbilical stump.

The second and third sutures were applied in the same manner in the right and left lower extremities (Figure 11).

In order to complete the umbilicoplasty, 3 simple points of suture were passed with 4.0 monocryl along the subdermal
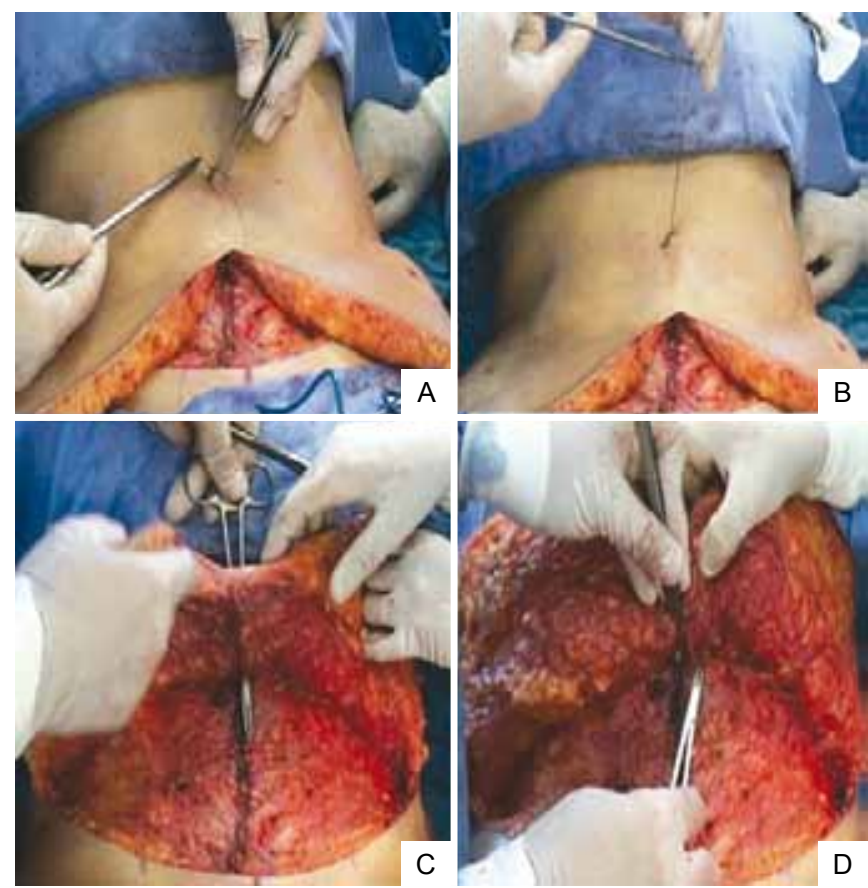

Figure 11 - Fixing the flap in the aponeurosis and the umbilical stump - second point: contralateral vertex in relation to the surgeon. In $\boldsymbol{A}$, a simple inverted point is made in the contralateral dermal vertex in relation to the surgeon. In $\boldsymbol{B}$, point passed in the dermal vertex and repaired by needle holder. In $\boldsymbol{C}$, a transfer maneuver of the repaired thread by the needle holder inside the hole of the abdominal flap. In $\boldsymbol{D}$, fixing the flap in the aponeurosis and the umbilical stump.

plane along the sides of the triangle. Therefore, it was possible to have an adequate coaptation of the edges of both triangles: along the flap and along the umbilical stump (Figure 12).

Abdominoplasty was performed with Baroudi sutures in the infraumbilical region close to the low transverse incision, fixing and gently pulling up the flap. At this point, a slight pull of the flap and marking of dermal-adipose tissue excess observed bilaterally were performed, followed by a resection and a lower incision suture.

All patients who underwent the surgical procedure signed an informed consent form routinely used in the service.

\section{RESULTS}

Among 198 patients who underwent abdominoplasty with triangular umbilicoplasty with dermal flap, 4 cases were excluded (all female) due to the impossibility of conducting the assessment for greater than 2 months. Therefore, this study included 194 patients (192 female and 2 male).

Regarding complications, 5 (2.58\%) cases of epidermolysis in the umbilical stump were observed, with complete resolution 
using moist dressing, despite the presence of postoperative hyperchromia. In another $3(1.55 \%)$ cases, a slight umbilical narrowing by scar retraction was observed, but with good resolution upon using silicone molds for 2 months. The most frequent stigmas associated with umbilicoplasty were not observed in this study, such as deletion after necrosis, scar narrowing requiring surgical intervention, enlargement of the umbilical scar circumference, lack of anatomical contours, irregular positioning, or even a streaky appearance caused by marks from external sutures.

Positive satisfaction was reported by patients in 188 (96.91\%) cases and by surgeons in $186(95.88 \%)$ cases.

In Figures 13 to 16, preoperative and postoperative images from 4 cases that were included in this study are presented.

\section{DISCUSSION}

Umbilicoplasty techniques in abdominoplasties, pioneered by Vernon, have been performed for over 80 years, although the search for improved outcomes continues to foster the development of newer surgical techniques. Recent studies comparing various methods of umbilicoplasty show that circular techniques have a 7 -fold greater relative risk of scar stenosis than non-circular techniques, such as the latest ones using "V", "Y" or inverted triangle shapes ${ }^{7,9}$.
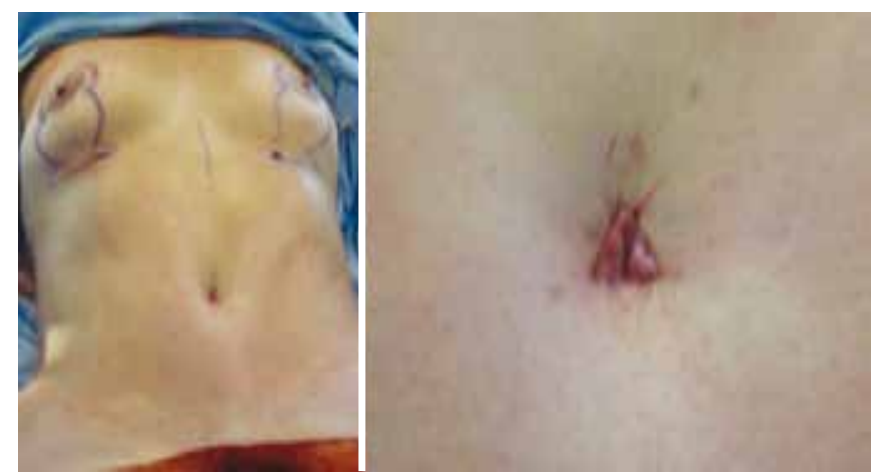

Figure 12 - Umbilicoplasty result (transoperative period).
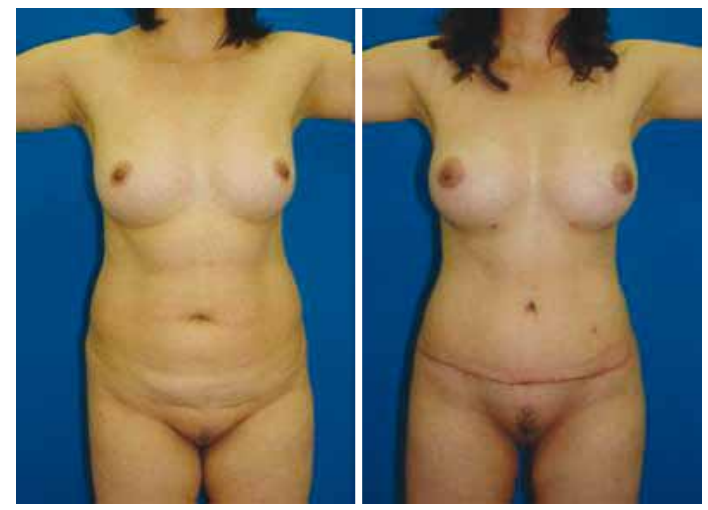

Figure 13 -Case 1: Pre-and postoperative periods.
The triangular umbilicoplasty technique with a skin flap has 2 major advantages over circular techniques. First, the triangular technique has a lower risk of scar narrowing ${ }^{10}$. Second, the dermis is maintained along the edges of each vertex of the triangle, providing a safe area for fixing the flap in the abdominal aponeurosis and the umbilical stump without incisions, thereby drastically reducing the possibility of suture dehiscence.
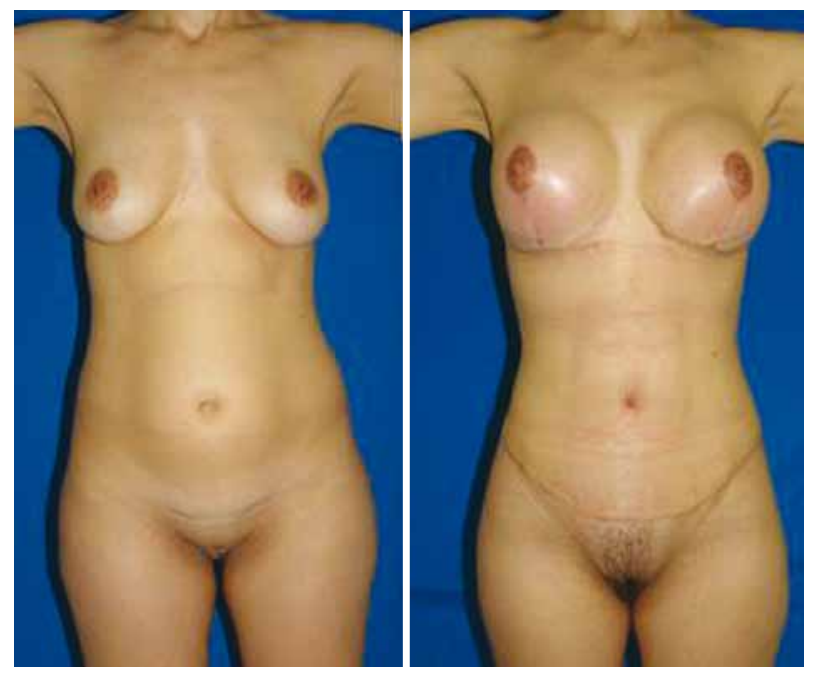

Figure 14-Case 2: Pre- and postoperative periods.

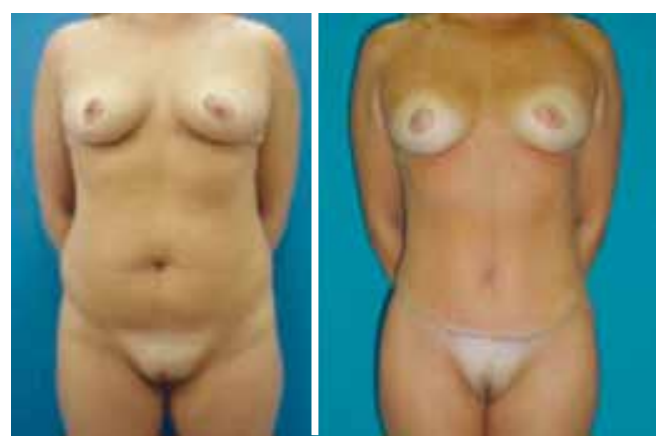

Figure 15-Case 3: Pre- and postoperative periods.
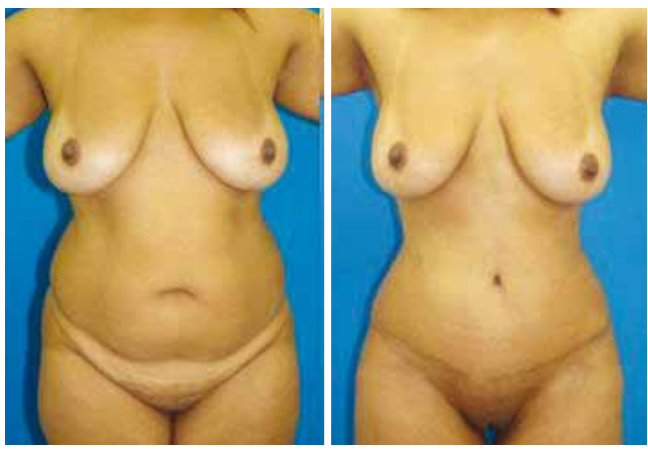

Figure 16-Case 4: Pre-and postoperative periods. 
Umbilical scar epidermolysis was associated with skin injury in cases of combined treatment of umbilical hernias, which occurred in $5(2.58 \%)$ patients. Scar narrowing occurred in $3(1.55 \%)$ patients, which was associated with the smaller size of the triangular hole created in the abdominal flap, leading to stenosis.

Importantly, the technique used in this study resulted in a high degree of satisfaction reported by both surgeons $(95.88 \%)$ and patients $(96.91 \%)$.

\section{CONCLUSION}

The triangular umbilicoplasty technique with a skin flap performed in this study demonstrated versatility, simplicity in implementation, and reproducibility, producing an umbilical scar of an adequate size and position. The scars were inconspicuous and, at times, even unnoticeable, providing greater harmony with the body contour and improved appearance of the umbilical scar, a major stigma of abdominoplasty.

\section{REFERENCES}

1. Sinder R. Abdominoplastias. In: Carreirão S, Cardim V, Goldenberg D, eds. Cirurgia plástica. Sociedade Brasileira de Cirurgia Plástica. São Paulo: Atheneu; 2005. p. 621-45.

2. Bozola AR, Bozola AC. Abdominoplastias. In: Mélega JM, ed. Cirurgia plástica: fundamentos e arte. (Plastic surgery: fundamentals and art) Cirurgia Estética. Rio de Janeiro: Medsi; 2003. p. 609-28.

3. Pitanguy I. Abdominoplastias. O Hospital. 1967;71(6):1541-56.

4. Pitanguy I. Abdominal lipectomy: an approach to it through an analysis of 300 consecutive cases. Plast Reconstr Surg. 1967;40(4):384-91.

5. Baroudi R, Keppke EM, Tozzi Netto F. Abdominoplasty. Plast Reconstr Surg. 1974;54(2):161-8.

6. Baroudi R. Umbilicaplasty. Clin Plast Surg. 1975;2(3):431-48.

7. Avelar JM. Abdominoplasty: systematization of a technique without external umbilical scar. Aesthetic Plast Surg. 1978;2:141-51.

8. D'Assumpção EA. Técnica para umbilicoplastia, evitando-se um dos principais estigmas das abdominoplastias. (Technique for umbilicoplasty, avoiding one of the major abdominoplasties stigmas) Rev Soc Bras Cir Plast. 2005;20(3):160-6.

9. Rosique MJF, Rosique RG, Lee FDI, Kawakami H, Glattstein N, Mélega JM. Estudo comparativo entre técnicas de onfaloplastia. (Comparative study between omphaloplasty techniques) Rev Bras Cir Plast. 2009;24(1):47-51.

10. Malic CC, Spyrou GE, Hough M, Fourie L. Patient satisfaction with two different methods of umbilicoplasty. Plast Reconstr Surg. 2007;119(1):357-61.

\section{Correspondence to:}

João Francisco do Valle Pereira

Av. Osvaldo Rodrigues Cabral, 1.570 - Ático - Centro - Florianópolis, SC, Brazil - CEP 88015-710

E-mail: xanico@vallepereira.com 